\title{
LEGAL ASPECTS OF DRUG-INDUCED STATEMENTS
}

\author{
LEON M. DESPRES*
}

I

$I^{N}$ N JUNE I946, the prosecuting authorities in Cook County, Illinois, administered sodium pentothal to a murder suspect who was under arrest. The murders committed had been so horrible, and the results of the injection were so dramatic, that American newspapers gave the incident greater publicity than had ever been given to the use of a drug to obtain a statement. The suspect was a seventeen-year-old boy, William Heirens, who was arrested in an attempted burglary. One of his fingerprints corresponded with a fingerprint found at the scene of a murder. While in police custody, Heirens appeared to be feigning amnesia and gave no direct answers to questions. The law-enforcing authorities then arranged for a psychiatrist to give him a series of injections of sodium pentothal, and learned that Heirens had committed three murders and a number of burglaries, ultimately found to exceed five hundred. Later, Heirens made a written confession, pleaded guilty, and was sentenced to imprisonment. Newspapers reported and most of them acclaimed the new "truth serum" for its contribution to the identification and conviction of a criminal. ${ }^{\mathrm{r}}$

A quarter of a century has elapsed since American law-enforcement authorities first used a drug to induce statements in criminal cases. In the Dallas County Jail, on February $\mathrm{r}_{3}$, I922, a physician injected scopolamine into two convicted criminals and established to his satisfaction that they were not guilty of the crimes charged. ${ }^{\mathbf{x}}$ For many centuries men have known that intoxicants release inhibitions and loosen tongues. Odysseus observed" that wine makes even a wise man "blurt out what were better left unsaid." Mexican Indians have used peyotl, a vegetable,

* Member of the Illinois Bar.

× Chicago Sun, p. r., col. 7 (July r 7, I946), p. I, col. 8 (July r8, r946); Chicago Daily News, p. 3, col. I (July 18, I946); New York Times, $\$ 4$, p. 9 (Aug. 4, I946); Chicago Tribune, p. 5, col. 3 (July I, I946), p. I, col. 3 (July 3, x946), p. 4, col. 4 (July I3, I946); see also Report of Dr. Foster Kennedy to the New York Academy of Medicine, reported in 29 Newsweek 54 (Jan. 27, I947); 2 Science Illustrated 62 (I947).

Ia House, The Use of Scopolamime in Criminology, 88 Tex. State J. Med. 259 (I927).

$=$ Odyssey, Book r4. 
to induce revelation of secrets. ${ }^{3}$ For a long time, anesthetists observed that patients under anesthesia often made spontaneous and revealing statements. ${ }^{4}$ However, the scientific use of drugs to induce statements began in Texas, in I922. The original discovery was made by a Texas physician, Dr. Robert E. House, who had used scopolamine as an anesthetic in obstetrical cases. He reported his observation as follows:

My attention was first attracted to this peculiar phenomenon, Sept. 7, r916, while conducting a case of labor under the influence of scopolamine. We desired to weigh the baby, and inquired for the scales. The husband stated that he could not find them. The wife, apparently sound asleep; spoke up and said: "They are in the kitchen on the nail behind the picture." The fact that this woman suffered no pain and did not remember when her child was delivered, yet could answer correctly a question she had overheard, appealed to me so strongly that I decided to ascertain if that in reality was another function of scopolamine. 5

Dr. House became an enthusiastic advocate of scopolamine as a means both of obtaining confessions from criminals and of clearing the innocent. He was the first to use the phrase "truth serum" in professional literature and he made wide claims for scopolamine, which later experience has narrowed. Of persons under its influence, he announced: "At a certain stage of the anesthesia they will reply to all questions propounded with childlike simplicity, with childlike honesty, without evasiveness, guilt, deceit, or fraud."

After 1922 , there are many recorded uses of scopolamine and other drugs in criminal cases. In I928, in Hawaii, hyoscine hydrobromide was used with attendant publicity on a suspect in a murder investigation. The suspect was arrested under highly incriminating circumstances. A handwriting expert, who later changed his mind, clearly identified the suspect's handwriting with that on a ransom note. Then, after a physician administered the drug, the suspect admitted writing the ransom note and described the procedure in detail. On emerging, he repudiated his confession. A second injection brought negative results. Shortly afterward, the real murderer was apprehended, and, as Lancet, the British medical periodical commented, "it thus became unnecessary to exhaust the resources of medicine in the attempt to extract a confession."”

${ }^{3}$ Father Nicholas de Leon in Camino del Cielo, cited in Goddard, How Science Solves Crime: "Truth Serum," or Scopolamine, in the Interrogation of Criminal Suspects, ro Hygeia 337 (1932).

4 Hart, Ebaugh, and Morgan, The Amytal Interview, 210 Am. J. Med. Sci. r25 (1945).

5 House, The Use of Scopolamine in Criminology, 18 Tex. State J. Med. 259, 26r (I927).

${ }^{6}$ House, Why Truth Serum Should Be Made Legal, 42 Medico-Legal J. 138, I47 (Ig25).

7 Cross-Examination under Anesthetic, 2I 5 Lancet 990 (I928). 
Scopolamine was used in Birmingham, Alabama, to obtain confessions from a group of "axe murderers." In I93I, a private crime detection organization in Chicago used it to learn the hiding place of stolen securities and the whereabouts of missing robbers. ${ }^{9}$ In Kansas City, in I935, police used it successfully to obtain a confession from a suspect who insisted that he had no conscious recollection of a murder he had committed while intoxicated. ${ }^{30}$ Dr. House used it on at least eighty-four criminals or suspects. ${ }^{\text {Ir }}$ At the University of Wisconsin, Dr. W. F. Lorenz used scopolamine and hyoscine hydrobromate [sic] extensively, and later sodium amytal, which he found preferable. He recorded three striking cases in which the use of the drug cleared innocent persons who had been held under highly incriminating circumstances, and one of whom had even falsely confessed the crime. ${ }^{12} \mathrm{By}$ I93I, the Scientific Crime Detection Laboratory of Northwestern University (now of the City of Chicago) had been experimenting with scopolamine "for some time." ${ }_{13}$ Undoubtedly, the recorded uses and studies are only a small part of all that might be found in the confidential records of police investigations and criminological research.

Since I929, paralleling the police use of drugs to obtain statements, psychiatrists have made tremendous progress in the use of sodium amytal and similar drugs to treat mental illness. Although the methods were foreshadowed by advanced medical research workers as early as 1882 , marked progress began only in I929..$^{14}$ For ten years before World War II, psychiatrists used intravenous injection of barbiturates-sodium amytal, evipan sodium, nembutal, and finally sodium pentothal-in part for the same immediate end as the police, to obtain uninhibited expression of repressed material by the subject. Remarkable results were obtained, and the process was variously called narcoanalysis, narcosynthesis, narcohypnoanalysis, and amytal or pentothal interview. ${ }^{x \bar{s}}$

8 House, op. cit. supra note 6 , at $I_{3} 8$.

9 Chicago Sun, p. 21, col. I (Aug. 7), r946:

so 26 Time 54 (Nov. 18,1935 ).

"2 House, op. cit. supra note 6.

"Lorenz, Criminal Confessions under Narcosis, 3I Wis. Med. J. 245 (1932).

23 House, The Use of Scopolamine in Criminology, 2 Am. J. of Police Science $32 S$ (193 $\mathrm{r}$ ).

is Greisinger, Mental Pathology and Therapeutics ( $18 S_{2}$ ); Starky, Light Ether Hypnosis, 9I Medical Record $6_{3}$ ( $\mathrm{IgI}_{7}$ ); Bleckwenn, Production of Sleep and Rest in Psychotic Cases, 24 Arch. Neur. and Psych. 365 (1930).

ss Palmer and Braceland, Six Years Experience with Narcosis Therapy in Psychiatry, 94 Am. J. Psychiatry 37 (1937); Horsley, Narco-Analysis, 82 J. Mental Sci. 416 (1936); Morrow, The Psychiatric Uses of Intravenous Sodium Amytal, 8 I Jel. State MIed. J. I1o (I936); Hart, Ebaugh, and Morgan, op. cit. supra note 4 . 
World War II brought a very great increase in the use of injections of barbiturates in acute mental illness under combat conditions. After the evacuation at Dunkirk in I940, British psychiatrists reported their extensive and successful experiences. ${ }^{16}$ After this country entered the war, American psychiatrists used the procedure with satisfactory results. ${ }^{17}$

The great recent increase in scientific medical knowledge and the exceptional publicity given to the sodium pentothal injections in the Heirens case demand consideration of the legal and other social problems raised by the use of drugs to obtain statements. If the drugs really produce the simple truth, there will be a great demand for their use.

What is the effect of sodium pentothal and related drugs? Drs. Sargant and Slater describe it as follows:

It is commonplace that under the influence of alcohol a man reveals tendencies that remain hidden in everyday life and may become suggestible, obstinate, euphoric, or boastful. Tongues are loosened by drink; critical judgment is suspended and secret aspirations, damaging confesșions, and dramatic falsifications of previous events come pouring out. Psychiatry has taken a trick and turned it into a technique. But what is now sometimes graced with the high-sounding title of "narcoanalysis" is no more than the method employed from time immemorial by the colonel in the mess to discover the qualities of the newest subaltern. Instead of alcohol, whose effects take some time to produce, are unreliable and difficult to control, we now employ a barbiturate to which these objections do not apply. But the effects are much the same. Both in the normal, the neurotic, and the psychotic, the drug abolishes inhibitions and allows underlying thought processes and preoccupations to appear. In addition, if there is much associated anxiety, this is partly at least abolished. The great value of the intravenous barbiturate for diagnostic purposes in the psychotic is sometimes not sufficiently realized. Under the influence of a suitable dose, the retarded depressive may become free, able to talk, and even cheerful. ... . There is reduction of the critical sense, an enhancement of rapport, and often a pouring out of both truth and fantasy equally. Aggressive feelings, which would terrify the individual in his normal state, can be expressed without excessive anxiety and the emotional experiences of the past can be lived anew without disturbances of the autonomic equilibrium..$^{8}$

The following description is given by Dr. W. F. Lorenz:

There are certain drugs which will produce a mental state in which consciousness is more or less profoundly affected. While in such a state of altered consciousness, an individual has lost a certain amount of control. He is unable to critically survey his re(r944).

${ }^{{ }^{6}}$ Sargant and Slater, An Introduction to Somatic Methods of Treatment in Psychiatry

${ }_{77}$ Grinker and Spiegel, Men under Stress, 170-77 passim (1945); Erb and Bond, Sodium Amytal Narcosis in Management of Emotional Disorders of Combat Flyers, 8 War Med. 146 (1945); Hastings, Glueck, and Wright, Sodium Amytal Narcosis in Treatment of Operational Fatigue in Combat Air Crews, 5 War Med. 368 (1944); Altman, Neuroses in Soldiers, 2 War Med. 267 ( $\left(r_{943}\right)$.

${ }^{28}$ Sargant and Slater, op. cit. supra note 16 , at III. 
sponses to questions. In such a condition his reactions are more or less automatic. The continuity of consciousness, that is, the continued awareness of events that are actually transpiring at the time is disturbed. His ability to associate thoughts, select, inhibit, or carefully choose those to be expressed is impaired. Depending upon the drug and the dose used, all degrees of disturbance of consciousness can be produced, ranging from a vague sense of slight bewilderment to complete disorientation or unconsciousness. Some drugs produce a delirium with vivid hallucinations, while others induce a state of narcosis without hallucinations. In short, there is no "truth serum," but a state of mind that can be induced by a variety of drugs. ${ }^{19}$

The authorities agree that the subject pours out both fact and fancy. Dr. Lorenz observes: "Much care must be exercised by the experimenter to evaluate the results. He must discriminate, if possible, what is the product of fantasy and what of fact."

Although some persons retain their characteristic defenses even under influence of the drug, ${ }^{2 x}$ the degree and effect of suggestibility are greatly heightened. ${ }^{22}$

In psychotherapy, the physician's skill depends on his obtaining recitals of internal, external, and mixed events, and on his ability to suggest developments and reconciliations. In law, we reject for untrustworthiness a method of interrogation which mingles external events with imaginary occurrences and shapes the answers of the subject to the suggestions of the examiner. Thus, however striking their medical uses, the drugs are not "truth serums"; they dissolve inhibitions and tend to stimulate unrepressed expressions of external fact, of fancy, and of suggestion.

\section{II}

Under American and British law, a criminal confession made under the influence of a drug would be inadmissible in evidence because of the rule against involuntary confessions. On this point, all writers on the subject agree. ${ }^{23}$ If a state court admitted such a confession, the United States

${ }^{2}$ Lorenz, op. cit. supra note $x 2$.

${ }^{20} \mathrm{Ibid}$., at 246 . Italics added.

${ }^{2}$ Sargant and Slater, op. cit. supra note 16 , at ir 5 ; Grinker and Spiegel, The Management of Neuropsychiatric Casualties in the Zone of Combat, in Solomon and Yakovlev, Manual of Military Neuropsychiatry 530 (I944); Hart, Ebaugh, and Morgan, op. cit. supra note 4, at I29; Morrow, op. cit. supra note I5, at II2.

${ }^{22}$ Altman, op. cit. supra note 17, at 271; Stungo, Evipan Hypnosis in Psychiatric Outpatients, 240 Lancet 507 (194I); Lorenz, op. cit. supra note I2, at 247 .

${ }^{23}$ Wigmore, Evidence $\$ \S 84 \mathrm{I}, 998$ (3d ed., r940); Wigmore, Science of Judicial Proof $\S 3 \mathrm{II}$ (3d ed., I937); Larson, Lying and Its Detection 204-20 (I932); McCormick, Deception-Tests and the Law of Evidence, 15 Calif. L. Rev. 484, 492, 503 (I927); Methods of Scientific Crime Detection as Infringements of Personal Rights, 44 Harv. L. Rev. 842, 845 (I93I); Inbau, SelfIncrimination-What Can an Accused Person Be Compelled To Do? $28 \mathrm{~J}$. Crim. L. and Criminology 26I, 288 (I937); Kleinfeld, The Detection of Deception-A Resume, 8 Fed. Bar J. I53, I67-7I (I947); see State v. Cole, 354 Mo. 181, I93, r88 S.W. 2d 43, 5I (1945). 
Supreme Court would reverse the conviction under its decisions that use of a coerced confession is not due process of law. ${ }^{24}$ The American Law Institute Model Code of Evidence has stated the bases of the rule as follows:

It is impossible to explain upon one theory all the cases dealing with improperly induced confessions. In some the exclusion seems to rest on nothing more substantial than the notion that an accused is entitled to a sporting chance. From a consideration of many others the deduction has been made that the moving, though unarticulated, reason is that prosecuting authorities are prone to rely too heavily upon confessions and to neglect the thorough investigation which they would otherwise make and which their duty demands; therefore the temptation to use improper inducements to obtain confessions must be removed. This is the primary theory of the Rule. Most of the judicial opinions, however, put the rejection of evidence of improperly secured confessions on the ground that there is great danger that such confessions may be false. ${ }^{25}$

On whatever basis the rule rests, a confession induced by a drug ought to be excluded. There is great danger that it may be false. It is subject to being mingled with fancy. It is subject to being molded by the suggestions of the interrogator. In the hands of incompetent or unethical interrogators, a suspect can make a wide variety of unreliable statements.

In conceding that courts should exclude confessions induced by drugs, writers have said that the use of drugs for that purpose had not yet received sufficient scientific acceptance. ${ }^{26}$ Perhaps the conclusion sometimes covers a revulsion at the oppressive uses to which the practice might be put by the authorities. By now, scientific investigation has not only advanced the medical uses of the drugs but has also revealed the unreliability of the confession for courtroom purposes by showing increasingly the subconscious elements which enter it. ${ }^{27}$

If the rule against involuntary confessions is designed to induce thorough investigation by the prosecutor, who might otherwise yield to the feeling that "it is far pleasanter to sit comfortably in the shade rubbing red pepper into a poor devil's eyes than to go about in the sun hunting up evidence," ${ }^{28}$ then certainly confessions induced by drugs ought to be excluded. Otherwise, the authorities might often be tempted simply to round

${ }_{24}$ Malinski v. New York, 324 U.S. 401 (1945); Ashcraft v. Tennessee, 322 U.S. I43 (I944), noted in 57 Harv. L. Rev. 9I9 (I944); Ward v. Texas, 3 I6 U.S. 547 (I942); The United States Supreme Court Interpretation of Admissibility of Criminal Confessions, $36 \mathrm{~J}$. Crim. L. and Criminology 222 (1945).

as Rule 505, Comment (C).

${ }^{26}$ Wigmore, Evidence $\$ 841,998$ (3d ed., 1940).

27 See Hudson, Psychological Problems Relating to Criminal Confessions of Innocent Persons, 18 Medico-Legal J. 84 ( 1900$)$, for a discussion of the influence of suggestion in inducing confessions from the innocent.

${ }^{28}$ I Stephens, History of Criminal Law 442 (I883). 
up suspects and inject drugs, instead of making a thorough investigation of all the circumstances of the crime.

The "sporting chance" notion for excluding involuntary confessions has often received contemptuous treatment from writers. Bentham derided it, calling it the "fox-hunters' reason." 29 However, it appears to have far more validity than the grace of the fox-hunter.$^{30}$ The individual citizen ought to be free from oppression by the law-enforcing authorities, and the use of drugs to obtain statements opens tremendous possibilities for oppression. On technically sufficient warrants, persons might be arrested and subjected to interrogation. Under the influence of drugs, their secrets, their wishes, their subconscious hostilities, would soon become police property, and many private details, better left hidden, could be used to embarrass or destroy the subject. Although the drug injection would lack the physical discomfort of torture, it would, nevertheless, be an effective method of torture whose results in ruined lives might far exceed the discomforts of the conventional third degree. Surely, on the basis of preventing unfair oppression, the rule is properly applied to exclude confessions induced by drugs. There might be no incongruity in the use of drugs in a system of Continental European criminal procedure which subjects the accused to inquisitorial cross-examination and permits both his silence and his speech to be used by the prosecution. More than fifty years ago, a Dutch statute expressly permitted the police authorities to use hypnotism for the purpose of obtaining information; but even there the statement itself was made inadmissible. ${ }^{3 \mathrm{r}}$

Courts have excluded as involuntary other confessions which resemble those induced by drugs. A confession which appeared to be made under hypnotic influence was held involuntary as was one made under the influence of a clairvoyant. ${ }^{32}$ At about the beginning of the century, the question of using confessions by hypnosis was widely discussed in the United States, and the medical and legal professions apparently agreed that suggestibility played too great a role in the confessions, because "even honest questioning may act as false suggestion." 33 A confession made in sleep is

${ }^{29}$ Bentham, Rationale of Judicial Evidence, bk. 9, c. 3.

${ }^{30} \mathrm{McC}$ Cormick, The Scope of Privilege in the Law of Evidence, I6 Tex. L. Rev. 447, 451-57 (1938).

${ }^{31}$ Hypnotism and the Law, 95 Law Times 500 (I893).

${ }^{32}$ Rex v. Booher, [1928] Dom. L. Rep. 795 (Alberta), noted in 42 Harv. L. Rev. 704 (1929); State v. Strong, 83 N.J.L. I 77, I88, 83 A. 506, 5 I0 (I9I2); see People v. Ebanks, II 7 Cal. 652, 49 Pac. 1049 ( 1897 ).

${ }^{33}$ Ladd, Legal Aspects of Hypnotism, Ir Yale L. J. 173 (1902); Bannister, Hypnotic Influence in Criminal Cases, 5 r Albany L. J. 87, 88 (1895); see Wigmore, Science of Judicial Proof § 3 II (3d ed., 1937). 
also involuntary; ${ }^{34}$ but since sleep, unlike the injection of sodium pentothal, is a phenomenon with which all men are acquainted, the Supreme Court of West Virginia, in I89I, was willing to trust a jury to decide whether a defendant was awake or asleep; and, if asleep, whether she was speaking the truth when she said: "They have devilled me so much about this that I don't care how it goes; I only consented to his death and gave him the poison." The court said:

It was a question of fact, which the jury was competent to decide, whether the prisoner was awake or asleep when the ejaculation was made. We must assume that it was discussed before the jury in lights applicable to the subject, to enable the jury to make an intelligent estimate of its weight. It was with them to say whether it was made in sleep, and was therefore worthless, or whether, though in sleep, it was but the divulgence of truth, springing from guilt which rested heavy on the soul, and broke forth tbrough voice and lips, the half conscious man revealing secrets, indelibly impressed on the memory, which, if fully awake, he would fain have suppressed. It was with the jury to say whether she was fully awake, and forgot herself, and in this soliloquy spoke out the truth. The operation of the human mind is an enigma, and its expressions in the unconsciousness of sleep are frequently vagaries and fictions, but sometimes born of reality. 35

Although the court's language sounds like a modern description of a subject under sodium pentothal, probably even the same court would not trust a jury to weigh a statement induced by the drug. Courts have also let juries decide the value of confessions made when a defendant was said to be intoxicated ${ }^{36}$ or hysterical. ${ }^{37}$

It might be argued that statements induced by drugs should be admitted on the same basis that courts receive the results of other involuntary physical tests. Courts have gone far in admitting evidence of physical tests, made in or out of court, which have been established as accurate..$^{8}$ Thus, many courts have admitted evidence of blood and respiration tests for intoxication, medical examination for pregnancy and diseases, fingerprinting, and even psychiatric examinations. ${ }^{39}$ Short of the invasion of a

34 People v. Robinson, I9 Cal. 4I (r86I).

${ }^{35}$ State v. Morgan, 35 W.Va. 260, 265, I3 S.E. 385,386 (I89r).

${ }^{36}$ Eskridge v. State, $25 \mathrm{Ala}$. 30 (1854).

37 People v. Lehin, 209 Cal. 336, 287 Pac. 337 (I930).

${ }^{38}$ State v. Graham, 74 N.C. 646 (I876).

${ }^{39}$ Inbau, op. cit. supra note $23 ; 25$ Ore. L. Rev. 270 (I946), noting State v. Cram, I76 Ore. 577, 160 P. $2 d 283$ (r945); Blood Test for Intoxication in Criminal Cases, I94I Wis. L. Rev. 249; Mamet, Constitutionality of Compulsory Chemical Tests to Determine Alcoholic Intoxication, $36 \mathrm{~J}$. Crim. L. and Criminology 132 (r945); Intoxication Tests as a Violation of the Privilege Against Self-Incrimination, 3 Wash. \& Lee L. Rev. I22 (I94I); Compulsory Bodily Action or Exhibition as Violating the Privilege against Self-Incrimination, I7 Minn. L. 
superior right of privacy or the infliction of direct pain or suffering on the accused, there is now no doubt that he can be compelled to exhibit his physical characteristics for many tests which have wide acceptance for accuracy. Does this tendency of the courts indicate that statements made under the influence of drugs may also be held to be admissible? In reaching their decisions, all courts and all text writers have said that the rules against self-incrimination and involuntary confessions refer to verbal utterances ${ }^{40}$ The breath, the blood, the fingers, and other organs will be allowed to present mute evidence under the interpretation of the tester; but words have been excluded. Even in ordering psychiatric examinations, courts have not ordered defendants to speak if they refused. ${ }^{4 x}$ Sustaining a lower court order for such an examination, the Supreme Court of Louisiana said: "He was forced to do nothing; he was looked at and spoken to; but even a cat may look at a queen, and no one need answer when spoken to unless he wishes to." ${ }^{2}$ The distinction between verbal and physical compulsion has a valid historical basis, because the abuses in compelling self-incrimination and involuntary confessions were predominantly concerned with verbal utterances; but the distinction seems to be based also on accepting the dualism of body and mind, admitting the evidence of the body, but not of the mind. Under the impact of modern psychology, the "mind" as generally conceived is fleeing to ever deeper recesses, leaving more and more functions to the "body." One day, verbal utterances may be deemed mere "physical characteristics," and the use of statements induced by drugs may be admissible in mixed courts of medicine and of law. So long, however, as the law holds a criminal responsible for his wilful crime and punishes him, it is unlikely that Anglo-American courts as we know them will hold forcibly obtained verbal statements equally admissible with footprints, fingerprints, and blood tests.

Most American courts do, however, make a fine distinction between confessions and admissions. ${ }^{43}$ Although a confession is admissible only if

Rev. I87 (1933); I3 U. of Kan. City L. Rev. I03 (1944), noting State v. Shannon, I82 S.W. 2d 384 (Ark., x944). Compulsory Subjection to Physical Examination by a Doctor as Violating the Privilege against Self-Incrimination, I7 Notre Dame Lawyer 243 (I942); Wigmore, Evidence $\$ 2265$ (3d ed., I940); Kemner, Power of Courts to Compel Defendants in Criminal Cases to Submit to Physical Examination, 4 Ind. L.J. 456 (xg29).

$1^{\circ}$ Holt v. United States, 218 U.S. 245, 252 (I9ro); Greenleaf, Evidence $\$ 469 \mathrm{c}$ (I6th ed., 1899); The Privilege against Self-Incrimination, 49 Yale L.J. I059, 1062 (1940).

${ }_{4}$ State v. Coleman, 96 W.Va. 544 , I23 S.E. 580 (I924); People v. Furlong, I87 N.Y. I98, 79 N.E. 978 (1924); Commonwealth v. DiStasio, 294 Mass. 273, I N.E. $2 d$ I89 (I936).

42 State v. Genna, I63 La. 70I, 7I4, II 2 So. 655, 660 (I927).

${ }^{43}$ Wigmore, Evidence $\$ 821$ (3d ed., r940); Wharton, Criminal Evidence $\$ \S 592,646$ (IIth ed., I935). 
it is voluntary, an admission need not be shown to have been made voluntarily. Wigmore explains the difference by saying that a confession is an acknowledgment "in express words by the accused in a criminal case of the truth of the guilty fact charged or of some essential part of it," while an admission is an acknowledgment "of subordinate facts colorless with reference to actual guilt." Since majority opinion admits involuntary admissions, there seems to be no obstacle to the admission in evidence of a mere involuntary admission, even if made under the influence of a drug. The distinction is a fine one and hardly seems realistic or desirable. ${ }^{44}$ Nevertheless, if a court could draw a distinction between a mere admission and a confession under the influence of a drug, the admission might be received.

The regularity of the law in refusing to admit confessions induced by drugs does not remove such drugs from the world nor settle the many problems raised by their increasing use. Although the prosecution is clearly foreclosed from offering the involuntary confession, the defense may want to offer a statement in proof of innocence. Dr. W. F. Lorenz of the University of Wisconsin reports that the use of drugs is far more effective in clearing the innocent. than confounding the guilty.45

May a defendant support his innocence by offering testimony of statements made while under the influence of a drug? The rejection of such an offer was sustained by the Supreme Court of Missouri in I926, which said:

It was sought to introduce in evidence the deposition of a doctor residing elsewhere, who testified to the effect that he had administered to the defendant what he termed a "truth-telling serum," and that while under its influence the defendant had denied his guilt. Testimony of this character-barring the sufficient fact that it cannot be otherwise classified than as a self-serving declaration-is, in the present state of human knowledge, unworthy of serious consideration. We are not told from what well this serum is drawn or in what alembic its alleged truth-compelling powers are distilled. Its origin is as nebulous as its effect is uncertain. A belief in its potency, if it has any existence, is confined to the modern Cagliostro, who still, as Balsamo did of old, cozen the credulous for a quid pro quo, by inducing them to believe in the magic powers of philters, potions and cures by faith. The trial court therefore, whether it assigned a reason for its action or not, ruled correctly in excluding this clap-trap from the consideration of the jury. Cogent reasons based upon numerous rulings, cited in the respondent's brief, bear ample testimony to support the wisdom of the court's ruling..$^{46}$

Undoubtedly, the ruling but not the language of the Missouri Supreme Court would be universally followed today even though modern psychi-

${ }^{44}$ Gorham, Involuntary Admissions Should Not Be Competent Evidence, Ig Temp. L. Q. 485 (I946).

45 Lorenz, op. cit. supra note 12 , at 249.

${ }_{46}^{6}$ State v. Hudson, 314 Mo. 599, 289 S.W. 920 (I926). 
atrists effect cures with sodium pentothal of which Cagliostro and Balsamo never dreamed. The unreliable nature of the statement and the suggestibility of the subject would make any court hesitate to disorganize a trial by allowing admission. Upon similar offers by defendants, courts have refused to admit in evidence the results of lie-detector tests involving blood pressure, pulse, respiration, electrical skin response, and muscular tension. ${ }^{47}$ Although widely used by police, by employers, by insurancè companies, and others to detect deception, the "lie detector" test has not yet established itself as sufficiently trustworthy to be admissible in evidence..$^{8}$ Undoubtedly, courts also give weight to the apprehension that a sincere but mistaken application of its use, much more an unscrupulous one, would impede trials. One court has refused to admit the tests of a lie detector, even on stipulation of both sides. ${ }^{48 a}$ By still stronger reasoning, the statement influenced by a drug would be excluded whether offered by prosecution or defense.

\section{III}

Even though the resultant statement is inadmissible, the authorities will undoubtedly continue to experiment with drugs and probably continue to use them to induce statements. It might readily occur that a suspect, when told that a drug would be administered, would make a full confession, perhaps in fear that otherwise even more crimes might be revealed. Would the confession be admissible? If the confession were made under the direct threat that a drug test would be administered, it would probably be excluded because made under a physical threat. But suppose an involuntary drug test were actually made, and later the suspect were informed, either truthfully or by trickery, that he had made a confession and were then induced or tricked into making a complete confession. Although English legal authorities reject the view that the state may use trickery to obtain confessions, ${ }^{49}$ American courts allow its use, so long, they say, as trickery is used in a manner calculated to obtain truthful results..$^{50}$

${ }^{47} 34$ A.L.R. 147 (1924); 86 A.L.R. 6 I6 (I933); Ir9 A.L.R. I200 (1939); I39 A.L.R. II74 (I942); contra: People v. Kenny, I67 Misc. 5I, 3 N.Y.S. $2 d$ 348 (I938), in effect overruled by People v. Forte, 279 N.Y. 204, r8 N.E. 2d 31 (1938); Smallwood, Lie Detectors: Discussion and Proposals, 29 Corn. L. Q. 535 (1944); Forkosch, The Lie Detector and the Courts, I6 N.Y.U. L.Q. Rev. 202 (r939).

${ }^{8}$ See People v. Becker, 300 Mich. 562, 2 N.W. 2d 503 (1942).

${ }^{48 \mathrm{a}}$ LeFevre v. State, 242 Wis. 4I6, 8 N.W. 2d 288 (I943).

${ }^{49}$ Non Tali Auxilio, 92 L.J. 204 (I942).

so Wigmore, Evidence $\$ 84 \mathrm{I}$ (3d ed.. I040): Commonwealth v. Hipple, 333 Pa. 33, 39, 3 A. $2 d 353,356$ (1939). 
Similar problems have accompanied the use of lie detectors. One of the values of using a lie detector is authoritatively said to be that "the instrument, the tests, and the accompanying procedures have a decided psychological effect in inducing admissions from guilty individuals." ${ }^{x}$ Recently the Illinois Supreme Court reversed a conviction because the prosecution offered a confession made while defendant was involuntarily subjected to a lie-detector test. The court said that the wrongful test "influenced, if it did not induce" the involuntary confession..$^{52}$ In Canada, the Alberta Supreme Court unhesitatingly rejected a confession made immediately after hypnosis by a Crown agent. ${ }^{53}$ Similarly, a confession induced after an involuntary drug interview should likewise not be admissible. Earlier decisions in other courts have admitted confessions made after inadmissible compulsory lie-detector tests, when defendants were induced to confess because they believed that the tests had demonstrated their guilt..$^{54}$

If the authorities persist in using drugs to obtain inadmissible involuntary statements, may they nevertheless use the facts learned through the statements, or are they barred from using the "fruit of the poisonous tree"? American courts permit the prosecution to use evidence discovered through the involuntary confession of an accused, even though the confession itself is inadmissible. ${ }^{55}$ The United States Supreme Court and a minority of the states have modified the rule, but only to reject the use of papers and things obtained by illegal search or seizure. ${ }^{6}$ The facts obtained are not "sacred and inaccessible" but may be proved if knowledge of them is also gained from an independent source. In a special group of cases, the cases of illegal wire tapping under the Communications Act of I935, the Supreme Court has prohibited the use of all evidence obtained as a direct result of such wire tapping, because the prohibition of wire-tapping evidence would be meaningless unless the court also prohibits the

${ }^{5 x}$ Inbau, The Lie Detector, 26 B.U.X. Rev. 264 (1946).

52 People v. Sims, 395 Ill. 69, 72, 69 N.E. 2d 336, 338 (I946).

53 Rex v. Booher, [I928] 4 Dom. L. Rep. 795.

54 State v. Dehart, 242 Wis. 562, 8 N.W. 2 d 360 (I943); Commonwealth v. Jones, $34 \mathrm{I} \mathrm{Pa.}$ 54I, I9 A. 2 d 389 (I94I); Commonwealth v. Hipple, 333 Pa. 33, 3 A. 2d 353 (1939), discussed in $x_{3}$ Medico-Legal and Criminological Rev. 202 (1945).

55 Wigmore, Evidence $\S 2$ I83 (3d ed., I940); 18 Tex. L. Rev. 504 (1940), noting Nardone v. United States, 308 U.S. 338 (I939).

${ }^{56}$ Silverthorne Lumber Co. v. United States, 25 I U.S. 385 (r920). Whether Harris v. United States, 67 S. Ct. 1098 (1947), heralds a modification of this rule cannot be determined until the courts have opportunity to decide whether the principle it announces is a contraction of the illegal search concept or of the illegal evidence concept. 
"fruit of the poisonous tree." 57 Even in these cases, however, the Supreme Court has said that the rule does not prohibit the use against a party of the facts learned by the illegal interception of evidence, if the connection is so attenuated as to dissipate the taint..$^{8}$

If the courts will permit the authorities to use any facts learned during drug interviews, is there not then a powerful incentive to use drugs to obtain information leading to admissible evidence? If the individual is to be adequately protected from the oppressive use of drugs, it would seem that the Supreme Court ought to construe due process to prohibit using the fruits of the involuntary confession. Such a result would impose no hardship upon prosecuting authorities. To avoid the confusion of proving which facts were learned properly and which by drug interrogation, the authorities need simply refrain from injecting the drug. If the rights of all individuals are to be effectively protected from promiscuous involuntary use of the injection, then courts must exclude any evidence obtained by its use, however attenuated. Otherwise:

To forbid the direct use of methods thus characterized but to put no curb on their full indirect use would only invite the very methods deemed "inconsistent with ethical standards and destructive of personal liberty."59

\section{IV}

How may an individual protect himself if the authorities threaten him with involuntary injection of a drug? Certainly he could obtain an injunction restraining such interference with his personal rights. ${ }^{60}$ The right to be free from interrogations by means of drugs seems clearly to be a right of privacy which courts protect.6r In 1940, a New Jersey court held that an individual's right of privacy was invaded even by a blood test to exclude paternity. The court said:

But if we admit such an encroachment upon the personal immunity of an individual where in principle can we stop? Suppose medical discovery in the future evolves a technique whereby the truth may infallibly be secured from a witness by trepanning his skull and testing the functions of the brain beneath. No one would contend that the witness could be forced against his will to undergo such a major operation at the im-

\footnotetext{
57 Nardone v. United States, 308 U.S. 338 (1939). But see United States v. Bayer, 67 S. Ct. I394, I398 (I947).

$5^{8}$ Ibid., at 34I.

59 Ibid., at 340.

${ }^{60}$ State v. Mayer (unreported), Superior Court of King County, Washington (Nov. 23, 1929), digested in National Commission on Law Observance and Enforcement, Report on Lawlessness in Law Enforcement I5I (1931).

6x Methods of Scientific Crime Detection as Infringements of Personal Rights, 44 Harv. L. Rev. 842,845 (I93I).
} 
minent risk of his life, in order to secure evidence in a suit between private parties. How then can he be forced to undergo a less dangerous operation, and at what point shall the line be drawn? To my mind, it is not the degree of risk to life, health or happiness which is the determinative factor, but the fact of the invasion of the constitutional right to personal privacy..$^{62}$

When the law has permitted a new scientific test to invade an individual's privacy, it has demanded at least accuracy before it permitted the invasion. But the use of drugs induces verbal statements which are subject to suggestion, contain a large and perhaps dangerous admixture of fact and fancy, include involuntary facts concerning his entire past life, and in addition may uncover his deepest wishes, his subconscious hostilities, and his personal secrets affecting both his life and the lives of others. There could hardly be a greater claim to the right of privacy nor a greater urgency for injunctive relief.

In many states, the extracting of involuntary confessions is penalized by statutes, which would also provide an additional basis for civil or criminal action. ${ }^{6}$ However, injunction procedure would often be too slow to prevent the completed act. Moreover, a suit for damages and a prosecution for violation of a statute would depend upon the willingness of a jury to assess damages and of the prosecuting authorities themselves to institute prosecution. Thus, the individual is left with no effective remedies against drug injections unless the courts exclude the "fruit of the poisonous tree" with such finality that prosecuting authorities will not be under any legal temptation to infringe on the rights of individuals. An individual would then be free, if he wished, to consent to a drug interview, if he felt that it would be helpful to him; but he would also be free from the risk of involuntary injection.

\section{V}

Since we can fairly expect that the authorities may continue to use drugs to induce statements, unless checked, what are the duties of the physician who administers the drug? If he administers it at the request of the prosecuting authorities for the purpose of obtaining an involuntary confession, he is a participant in their act and shares their legal responsibility. In his case, however, the possibility of revocation of license must be added to other possible consequences. Dr. W. F. Lorenz says that in a criminal investigation, no physician should ever administer a drug to induce a state-

${ }^{62}$ Bednarik v. Bednarik, I8 N.J. Misc. 633, 652, I6 A. 2 d 80, 90 (I940), noted in 89 U. of Pa. L. Rev. 518 (194r). (I93I).

$6_{3}$ National Commission of Law Observance and Enforcement, op. cit. supra note 6o, App. 3 
ment except in the presence of a representative of the suspect, and then only after full explanation and consent. ${ }^{64}$

Suppose, however, that in the course of his proper medical use of sodium pentothal, the physician hears a confession of a crime. May he reveal the crime? Must he reveal it if questioned? Since mentally ill people include many persons who are criminals as a result of their illness, there should be an assurance that the criminal personality who seeks the best mental treatment, like the penitent who seeks absolution, should be free to seek. it and receive it without fear that his deeds would thereby be revealed. The Hippocratic Oath lays the following moral obligation on the physician:

What I may see or hear in the course of the treatment or even outside of the treatment in regard to the life of men, which on no account one must spread abroad, I will keep to myself holding such things shameful to be spoken about.

Undoubtedly, most physicians have high personal standards safeguarding the confidences of the patient. Nevertheless, the common law and the law of approximately one-third of our states recognize no legal privilege in the communication from patient to physician; and the remaining states limit the privilege to information necessary to enable the physician to act professionally. ${ }^{65}$ In those states which recognize the privilege, a psychiatrist ought to be successful in establishing that any statement made in a sodium pentothal interview constitutes information necessary to enable him to act professionally.

The drugs have been highly useful in identifying victims of amnesia who are unable to give their names and addresses. ${ }^{66}$ If other means are exhausted, ought not the law-enforcing authorities to be permitted to have a physician use sodium pentothal so as to restore the victim to his proper environment? Even if in the course of such an exploration, a physician inevitably hears a confession of a crime, it would seem that the patientphysician privilege, where it exists, should protect him from disclosure, on the theory that all the disclosures made during the interview are necessary to enable him to act professionally; and his ethical standards ought to require him to conduct the examination privately so as to limit his work to

${ }^{6}$ Lorenz, op. cit. supra note $\mathrm{r} 2$, at $248,249$.

${ }^{65}$ Wigmore, Evidence $\$ 2380$ (1940); Chaffee, Privileged Communications: Is Justice Served or Obstructed by Closing the Doctor's Mouth on the Witness Stand? 52 Yale L.J. 607 (I943); Physician and Patient, I83 Law Times 337 (1937).

${ }^{66}$ Morrow, op. cit. supra note I5, at II2. Mosier and Harnes, The Identification of an Amnesia Victim by the Use of Scopolamine-An Experiment, $26 \mathrm{~J}$. Crim. L. and Criminology 43 I (I935). 
medical care and guard against disclosure of utterances except through his medical report. Although in some cases, the physician who examines or treats a suspect in police custody is held to be acting as physician for the state and to be outside the physician-patient privilege, ${ }^{67}$ in no case has he been permitted to testify to involuntary verbal communications.

Although the therapeutic use of sodium pentothal and related drugs by physicians ought to be encouraged in every way, and although suspects should be free to use it before trial under proper safeguards to assure a voluntary decision, the involuntary use of such drugs on criminal suspects is premature until society fully accepts the principle and practice that lawbreakers are to be treated and corrected rather than punished, and that the aim of criminal administration should be the speedy cure, rehabilitation, and restoration of the criminal without regard to traditional ideas of retribution and public punishment. So long as the state enacts laws to punish lawbreakers, and so long as the enforcement of such punishment can be directed or withheld by prosecuting authorities, the use of drugs to induce statements can be a powerful force for the oppression of individual citizens. We may expect that people closely identified with law-enforcing authorities will press for the widespread police use of such drugs in all criminal cases. Such a use would threaten everyone, without exception, save for those in ultimate control of political power. The drugs could be used to explore the life and thoughts and wishes of anyone on whom the authorities choose to use them.

One serious proponent of widespread use of such drugs to obtain statements in criminal cases has announced that the struggle to legalize their involuntary use will be "long and bitter." ${ }^{8}$ Under our present system of laws, the struggle to legalize the involuntary use of such drugs will not only be long and bitter but probably unsuccessful as well.

${ }^{67}$ Leard v. State, 30 Okla. Crim. I9x, 235 Pac. 243 (I925); State v. Coleman, 96 W. Va. 544 , I23 S.E. 580 (1924).

${ }^{68}$ Goddard, How Science Solves Crime: "Truth Serum," or Scopolamine, in the Interrogation of Criminal Suspects, Io Hygeia 337 (I932). 